Journal of Urban and Regional Analysis, vol. VII, 2, 2015 , p. $113-127$

\title{
THE DEVELOPMENT OF STREET PATTERNS IN ISRAELI CITIES
}

\author{
Itzhak OMER, Orna ZAFRIR-REUVEN \\ Department of Geography and Human Environment, Tel-Aviv University, Israel
}

\begin{abstract}
Street patterns of Israeli cities were investigated by comparing three time periods of urban development: (I) the late $19^{\text {th }}$ century until the establishment of the state of Israel in 1948; (II) 1948 until the 1980s; and (III) the late 1980s until the present. These time periods are related respectively to the pre-modern, modern and late-modern urban planning approach. Representative urban street networks were examined in selected cities by means of morphological analysis of typical street pattern properties: curvature, fragmentation, connectivity, continuity and differentiation. The study results reveal significant differences between the street patterns of the three examined periods in the development of cities in Israel. The results show clearly the gradual trends in the intensification of curvature, fragmentation, complexity and hierarchical organization of street networks as well as the weakening of the network's internal and external connectivity. The implications of these changes on connectivity and spatial integration are discussed with respect to planning approaches.
\end{abstract}

Key Words: street pattern, planning approach, urban morphology, Israeli city.

\section{Introduction}

The spatial form of cities in Israel has been studied while focusing mainly on the processes and ideologies involved in the creation and establishment of its urban system (Alterman and Hill 1986, Brutzkus 1964, Efrat 2004, Marom 2014, Rotbard 2015). Those who have dealt with the spatial forms of the built urban environment have concentrated primarily on small-scale studies at the level of building clusters, blocks, streets, neighborhoods and quarters (Aravot and Militanu 2000, Battat - Aviram 2014, Cohen and Amir 2008, Hatuka et al. 2012, Jacobson 2013, Marom 2009, Paldi and Wolssohn 1989) with little attention directed to the city level, especially regarding street patterns.

The creation of Israel's urban space, including the street network, was mainly done in the $20^{\text {th }}$ century. Prior to Israeli independence in 1948, urban space was developed according to the pre-modern planning approach, characterized mainly by a street pattern that is nearly orthogonal, and oriented toward pedestrian movement (Omer et al. 2015). In contrary, the space planned after the independence followed modern and late-modern planning approaches based on the hierarchical classification of streets, with a strong orientation toward vehicle movement (Aravot and Militanu 2000, Rofè and Omer 2012). These two general street pattern types in Israeli cities were investigated with respect to the integration level of the street network (Omer and Zafrir-Reuven 2010), walkability level and pedestrian volume distribution (Omer et al. 2015, Lerman and Omer 2013) and land use distribution (Omer and Goldblatt 2015). However, no comprehensive study was conducted on the characterization and classification of street patterns that exist in the Israeli urban space.

The aim of the present study is to identify and characterize the street patterns found in Israeli cities according to the urban planning approaches - pre-modern, modern and late-modern - 
that dominated three periods: $(I)$ the late $19^{\text {th }}$ century until the establishment of the state of Israel (1948); (II) 1948 until the 1980s; and (III) the late 1980s until the present. Due to the intensive development of new cities in each of these periods, Israel provides an appropriate setting for the examination of the effects of each urban planning approach on the urban street network.

In the following sections we first discuss the role of the street network as an urban form reflecting and constructing the social and cultural context. We then briefly present the types of cities found in Israel as well as the features of their development and their street patterns. A description of the relevant methods for the characterization and classification of street patterns and the method chosen follow afterwards. Finally, we summarize and discuss our results.

\section{Street Patterns and Urban Form}

Traditional and modern urban morphology research has considered the street network as one of the basic elements of urban form (Hillier 1987, Kropf 2009, Marshall 2005, Moudon 1994, Moudon 1998, Oliveira 2013). Some studies have used urban street patterns to characterize the nature of the physical form of cities in a particular country, society or culture (Asami et al. 2001, Bonine 1979, Porta et al. 2012, Read 1999, Strano et al. 2013). Other studies have used street patterns to learn about the evolution of urban form over significant periods connected to the development of metropolitan areas (Southworth and Owens 1993, Wheeler 2008). Due to these studies and many others, it is clear that street network is a primary element of urban form that serves as the skeletal structure of urban space with important effect on the function of cities.

Despite the fact that the street pattern is only one of a city's features, it provides fundamental indications about the phases of a city's development and the forces behind this development (Anderson 1992, Asami et al. 2001, Bonine 1979, Oliveria 2013, Read 1999, Southworth and Owens 1993). For example, studies starting from the 90's show that the most recent patterns, those characterizing the suburbia and urban sprawl, are disconnected and serve to further fragment the urban space (Filion and Hammond 2003, Song and Knaap 2004, Wheeler 2008).

Generally speaking, the differences between street pattern types are related to urban planning approaches (Hebbert 2005, Marshall 2005). Areas which were created following pre-modern concepts are characterized mainly by a street pattern that is nearly orthogonal, and without a clear hierarchical classification of streets. In contrast, areas that were established and developed during the second half of the $20^{\text {th }}$ century, under modern planning concepts, are characterized by a tree-like street pattern associated with the concepts of 'functional hierarchy' of street networks and the 'neighborhood unit' (Rofè and Omer 2014). The concept of 'functional hierarchy' aimed to separate traffic movement from accessible land uses while the concept of 'neighborhood unit' was suggested to design a functional infrastructure for residential communities. Thus, these street networks are vehicle-oriented and aimed to create safe and proximate communities by means of closed street patterns, cul-de-sacs and wide roads leading fairly directly from one neighborhood to another within the city (Filion and Hammond 2003, Marshall 2005, Southworth and Ben-Joseph 1995, Southworth and BenJoseph 1996).

The differences between street patterns are also associated with the pedestrian volume distribution and walkability level (Baran et al. 2008, Hajrasouliha and Yin 2014) and with the distribution of non-residential land use (Porta et al. 2012, Scoppa and Peponis 2015). Street patterns have also a great impact on the social dimension of the urban environment (Grannis 2005, Jacobs 1993, Southworth and Ben-Joseph 1996). For example, in the empirical studies conducted in several American cities, Grannis (2005) found that racial similarity among 
neighborhoods, like metropolitan macro-level segregation, emerged primarily by means of spatial connections constructed through tertiary street networks rather than simple geographical distance. More specifically, racial similarity emerged between neighborhoods connected through internal pedestrian streets, a trend that was limited by the presence of nonpedestrian streets. Grannis (2005) called this kind of neighborhood a 't-community' so as to indicate the role of pedestrian-oriented tertiary streets in creating social communities and neighborhoods.

The consideration of street networks effect on the perception of the urban built environment is demonstrated by concepts such as 'experiential network' - the pattern formed when the street networks lack continuous boundaries (Stanton 1986), or 'street neighborhood networks' urban neighborhoods formed of short blocks (Jacobs 1961). Street networks are also integral components of perceived neighborhoods which represent subjectively bounded neighborhoods or territories (Schnell et al. 2005). Lynch (1960) describes the function of street networks in the spatial cognitive representation of urban areas as follows: "The paths, the network of habitual or potential lines of movement through the urban complex, are the most potent means by which the whole can be ordered" (Lynch 1960: 96).

Street patterns are directly relevant to three of the urban environment's physical characteristics - differentiation, complexity and visibility - each of which can potentially affect the human experience and spatial behavior (Cubukcu and Nasar 2005, Montello 2007). Differentiation (distinctiveness) is the degree to which networks have a unique layout; in the case of streets, differentiation implies the ability to distinguish street network 'parts' according to the density, length and form of their streets. Complexity refers to the relations, composition and organization of these street networks. Visibility or visual access is the degree to which the different parts of the street networks (streets or segments of streets) are connected through vistas or visual lines. These morphological features are used in the current research to describe and classify the development of streets patterns in Israeli cities.

\section{Analytical Framework}

\section{Selecting Case Studies}

Previous studies have identified several types of cities in Israeli, each of which characterizes different periods and stages in Israel's development, and represent diverse political, cultural and social engines as well as planning approaches (Aravot and Militanu 2000, Efrat 1984). These city types are also characterized by typical street patterns (Pharhi and Zafrir 2003, Zafrir -Reuven 2006, Omer and Zafrir-Reuven 2010), as illustrated in Fig. 1 by street networks of selected cities:

Old cities - founded up to 1880 , often centuries before the beginning of the Zionist settlement at the end of the $19^{\text {th }}$ century (Fig. 1a). The number of old Jewish cities is relatively small; only five of them still exist as cores of contemporary functioning cities.

Moshavot - agriculture settlements founded after 1880. They represent the beginnings of the Zionist settlement (Fig. 1b).

Semi-agriculture suburbs - established during the 1920s and 1930s, they functioned partially as agriculture settlements (primarily domestic and limited) but also - and currently mainly - as a residential option for industrial workers and professionals (Fig. 1c).

New towns - these towns were established after 1948. They represent the first urban expression of nascent post-independence Israeli sovereignty. These cities are generally divided into two subgroups, according to the period of their establishment: early new towns 
(Fig. 1d) and late new towns (Fig. 1e).

a) Old city - Ako (Acre)

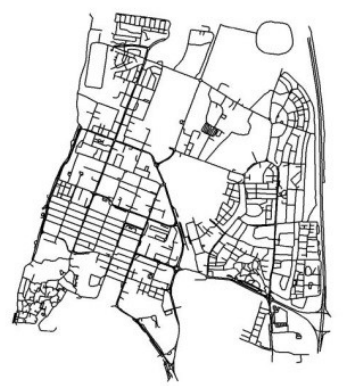

c) Semi-agriculture suburb Bat-Yam
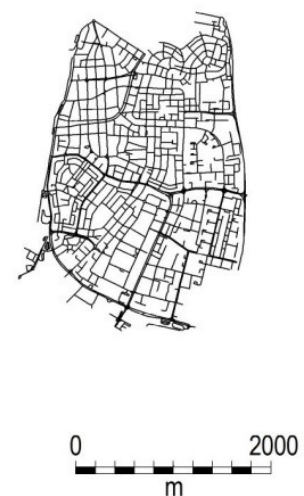

b) Moshava - Hadera

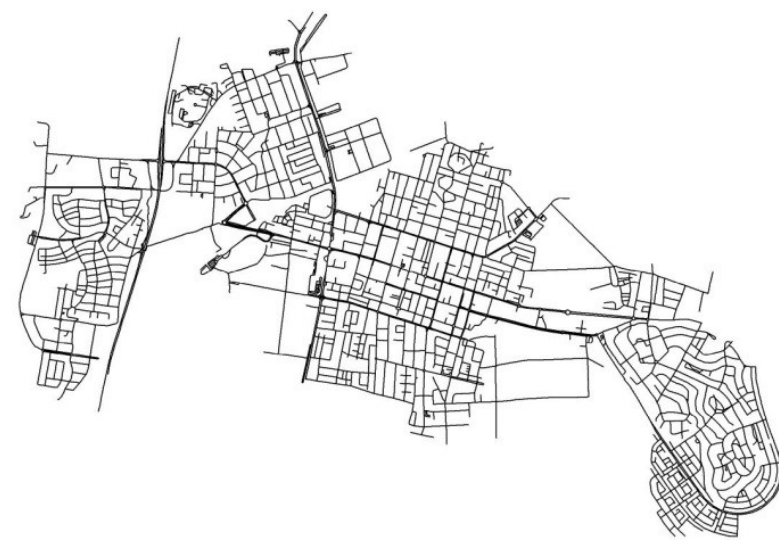

d) Early new town - Eilat

e) Late new town - Ashdod

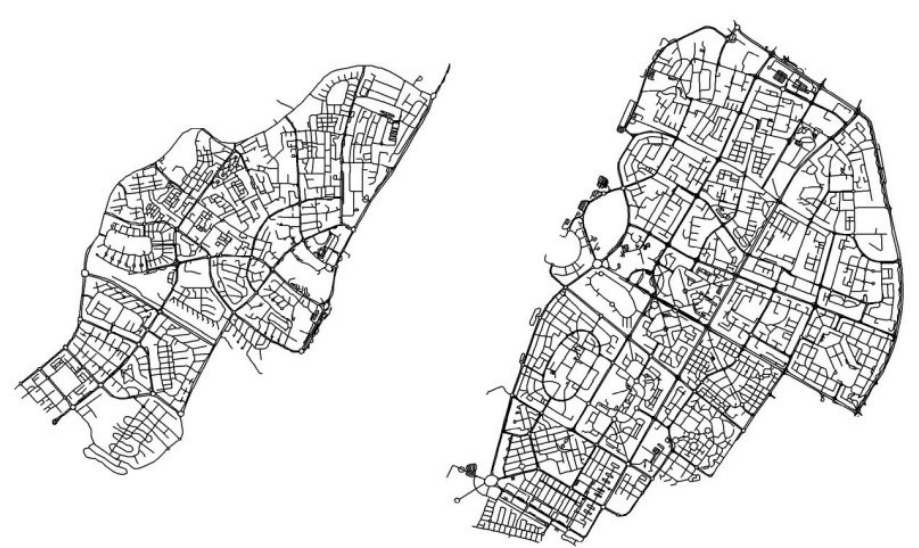

Fig. 1 - Examples of city types and their street patterns

The literature also defines a type of city called central or metropolitan city that refers to the three largest cities in Israel. It is worth noting that each central city includes the street patterns presented in Fig. 1.

As mentioned above, the distinction between these city types or urban areas is related to the urban planning approaches or doctrines by which they were established: urban environments established between the end of the $19^{\text {th }}$ century and the establishment of the State (1948) 
according to the pre-modern planning approach; urban environments established between 1948 until the 1980s according to the modern planning approach; and urban environments established from the 1980s until the present according to the late-modern planning period (Aravot and Militanu 2000, Farhi and Zafrir 2003, Omer and Zafrir-Reuven 2010, Zafrir-Reuven 2006).

Seven cities were selected to represent the street patterns of the respective planning approaches, having networks constructed in different periods: Hadera, Netanya, Raanana and Rishon Le-Zion (Moshavot), Bat-Yam (Semi-Agricultural Suburbs), Ashdod and Eilat (New Towns) (Fig. 2a). These cities represent well the distinction between city types in Israel (Omer

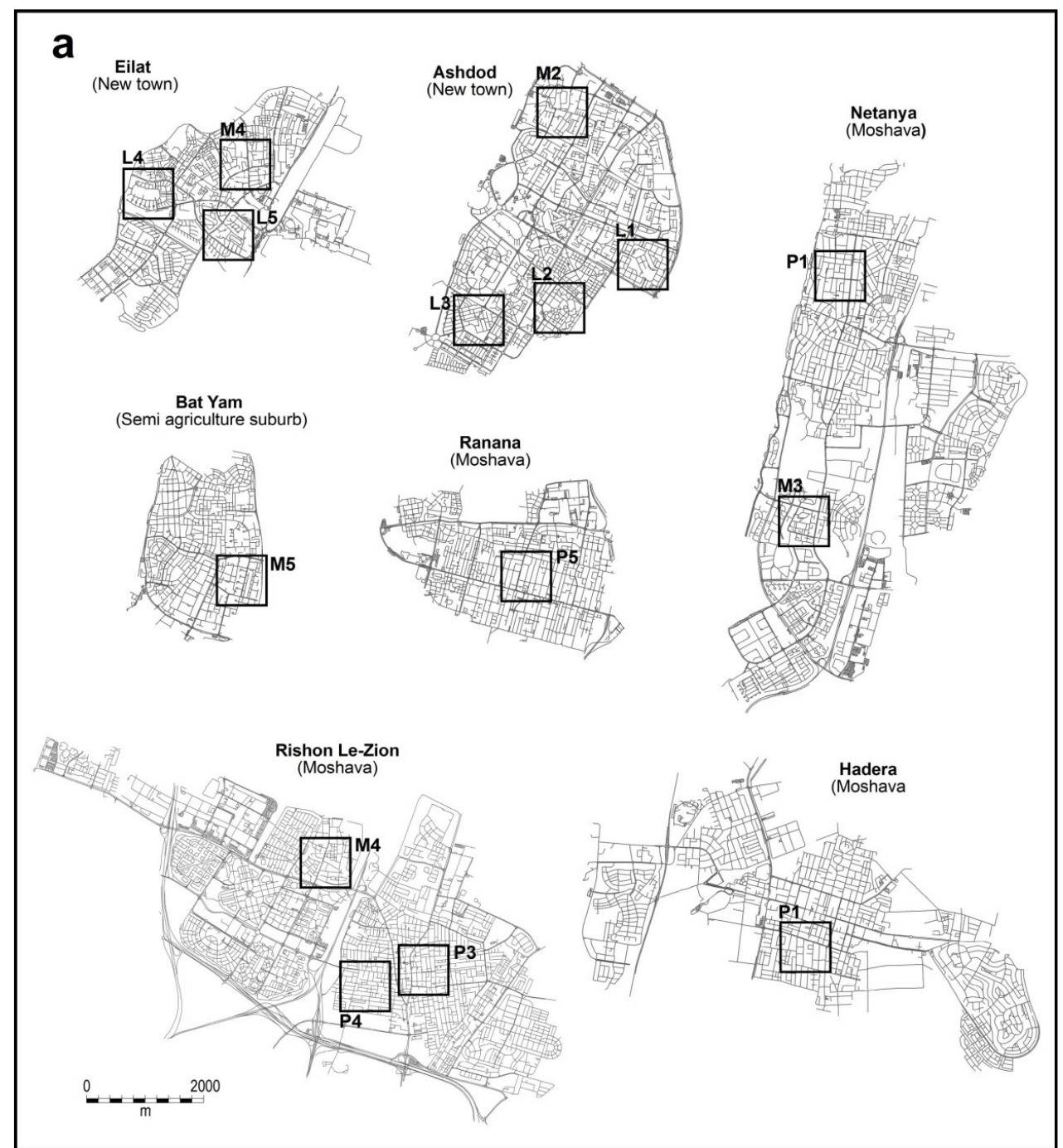

Fig. 2 - (a) Representative street networks from different periods in the selected Israeli cities. $P(n)=$ Sample of the pre-modern street network, $M(n)=$ Sample of the modern street network, $L(n)=$ Sample of the late-modern street network. 
and Zafrir-Reuven 2010) as well as different geographical areas in Israel e.g. metropolitan areas and periphery. We used several sources to identify and determine the street patterns for each period: historical maps, aerial photographs as well as GIS layers, with the last serving as the basis for the analysis. Since not all cities have been mapped continuously, we also used local planning documents found in municipal planning departments to determine the exact dates of the establishment of neighborhoods and areas. A sample of 15 representative street networks (square areas of $750 \mathrm{~m} \times 750 \mathrm{~m}$ ), 5 from each of these three periods were selected (Fig. 2b). These street network 'patches' are selected according to the period of establishment

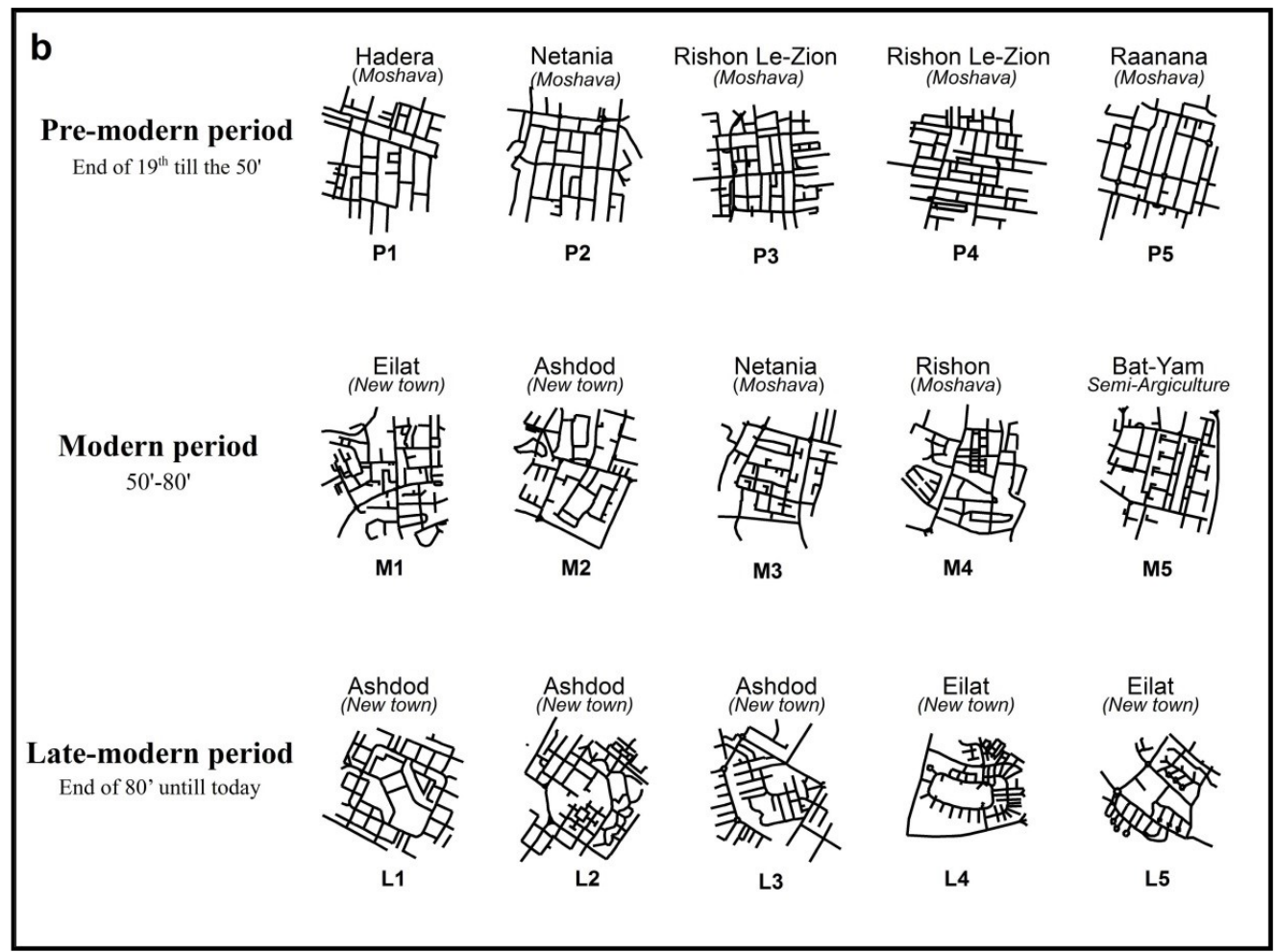

Fig. 2 - (b) Representative street network 'patches' of the examined periods/planning approaches. $P(n)=$ Sample of the pre-modern street network, $M(n)=$ Sample of the modern street network, $L(n)=$ Sample of the late-modern street network.

and their geographical location (e.g. the historical center of the city and new areas in the periphery) and the ability to isolate them from their immediate environment. The analysis aimed to reveal the morphological changes that characterize the development of street patterns in the Israeli urban space.

\section{Analysis Methods}

The study of street patterns includes issues of shape, form and composition to understand their basic characteristics and their evolution. Previous studies have classified street networks with descriptive tools and tagged them into prototypical names: Organic pattern, Grid, Orthogonal, Rectangular, Curvilinear, Tree, Capillary and so forth (Kostof 1993, Marshall 2005, Moudon 1992, Southworth and Ben-Joseph 1996, Southworth and Owens 1993). However, the 
combination between the quantitative traditional Conzenian approach and the quantitative approach, particularly the space syntax approach (Hillier 1996), enables us to investigate and classify the street networks with more objective criteria (Filion and Hammond 2003, Ozbil et al. 2011, Strano et al. 2013). More specifically, consideration is generally given to the geometric and configurational aspects of street patterns: length of lines, degree of curvature, number of intersections, number and size of blocks, connectivity, integration, fragmentation (Hillier 1996, Marshall 2005, Oliveira 2013, Southworth and Owens 1993). These features are applied with methods using topological, geometrical and metric terms that might also be relevant to human spatial behavior as well as for social and culture dimensions of cities (Hillier 1987, Hillier and lida 2005, Jiang 2007, Porta et al. 2006).

In order to describe and classify the development of streets patterns in Israeli cities in the current research we analyzed and measured the 15 selected street network 'patches' (Fig. 2a) according to the metric, geometric and topological features suggested in previous researches. More specifically, we concentrated on the following main morphological properties of street networks: curvature, fragmentation and fraction, spatial connection to the city, continuity and differentiation. Five variables were chosen to reflect these following morphological properties. We analyzed them on the basis of the measurements of different parameters in each of the street network 'patches', shown in Table 1.

Table 1

Morphological variables in selected street networks

\begin{tabular}{|c|c|c|c|c|c|c|c|}
\hline $\begin{array}{l}\text { Sam- } \\
\text { ples }\end{array}$ & City and Period & $\begin{array}{l}\text { No. of } \\
\text { streets }\end{array}$ & $\begin{array}{l}\text { No. of } \\
\text { Axile } \\
\text { lines }\end{array}$ & $\begin{array}{l}\text { No. of } \\
\text { Cul de } \\
\text { sacs }\end{array}$ & $\begin{array}{l}\text { No. of } \\
\text { Blocks }\end{array}$ & $\begin{array}{l}\text { No. of all } \\
\text { Junc- } \\
\text { tions }\end{array}$ & $\begin{array}{c}\text { No. of } \\
T \\
\text { Junc- } \\
\text { tions }\end{array}$ \\
\hline P2 & Pre-modern- Netania & 53 & 46 & 5 & 18 & 29 & 23 \\
\hline P3 & $\begin{array}{l}\text { Pre-modern (sample 1) - } \\
\text { Rishon Le-Zion }\end{array}$ & 62 & 61 & 7 & 29 & 43 & 33 \\
\hline P4 & $\begin{array}{l}\text { Pre-modern (sample 2) - } \\
\text { Rishon Le-Zion }\end{array}$ & 54 & 58 & 3 & 29 & 47 & 37 \\
\hline $\mathrm{P} 5$ & Pre-modern - Raanana & 34 & 39 & 5 & 16 & 27 & 21 \\
\hline $\mathrm{P} 1$ & Pre-modern -Hadera & 39 & 45 & 7 & 21 & 43 & 37 \\
\hline M3 & Modern - Netania & 31 & 45 & 18 & 14 & 26 & 21 \\
\hline M4 & Modern -Rishon Le-Zion & 42 & 61 & 13 & 17 & 44 & 38 \\
\hline M1 & Modern - Eilat & 53 & 97 & 24 & 12 & 45 & 42 \\
\hline M2 & Modern - Ashdod & 28 & 67 & 26 & 13 & 22 & 15 \\
\hline M5 & Modern - Bat Yam & 30 & 62 & 14 & 18 & 36 & 33 \\
\hline L1 & $\begin{array}{l}\text { Late-modern (sample 1) - } \\
\text { Ashdod }\end{array}$ & 43 & 56 & 11 & 18 & 22 & 30 \\
\hline L2 & $\begin{array}{l}\text { Late-modern (sample 2) - } \\
\text { Ashdod }\end{array}$ & 25 & 59 & 16 & 16 & 46 & 36 \\
\hline L3 & $\begin{array}{l}\text { Late-modern (sample 3) - } \\
\text { Ashdod }\end{array}$ & 46 & 69 & 29 & 14 & 22 & 17 \\
\hline $\mathrm{L} 4$ & Late-modern (sample 1) - Eilat & 61 & 84 & 21 & 18 & 29 & 26 \\
\hline $\bar{L} 5$ & Late-modern (sample 3) - Eilat & 33 & 64 & 10 & 19 & 36 & 31 \\
\hline
\end{tabular}

Curvature was measured by the ratio between the number of streets and the number of axial lines. Axial lines are defined as the longest straight lines of direct visibility and movement that pass through streets and open spaces, thereby creating a continuous network (Hillier 1996). This measure indicates movement options having possible implications on environment perception (Montello 2007). A curved or broken street will exhibit several axial lines while a straight street will exhibit only one. We can therefore expect orthogonal patterns to have low curvature ratio values while curved patterns will have high values. 
Fragmentation and fraction are measured by the ratio of cul-de-sac streets within the street network. We expect to find higher ratios of cul-de-sac streets in newer street patterns in light of the modern planning aspects of enclosure, neighborhood unit and hierarchical organization of street networks (Hebbert 2005).

Spatial connection is measured by the number of connecting routes - access lines - that link a given street pattern to the entire city's street network. Again, modern urban street patterns are characterized by high levels of enclosure, particularly at peripheral locations in the city. Therefore, these patterns were expected to exhibit a limited number of access lines or External connectivity (Song and Knaap 2004).

Continuity is measured by the percentage of $\mathrm{T}$ junctions out of all junctions. The basic assumption is that T-junctions will be much more dominant in modern and late-modern patterns (Marshall 2005).

Differentiation is measured by the total area of city blocks - an area fully bounded by streets - in each pattern. The assumption is that pre-modern patterns exhibit many city blocks, with the amount decreasing in modern and late-modern patterns, where the existing of dead-end roads, pedestrian trails, curved and hierarchical street networks create large lots with scattered blocks. The ratio between the number of blocks and the number of axial lines in each street pattern was chosen to describe this property.

The calculation and examination of the different measures were conducted with a GIS software (ArcGIS 10) and a Depthmap software (version 10.14). Depthmap (Turner 2004) was used to construct and measure axial lines. We also estimated ANOVAs in order to test the level of statistical significance of the differences between the street patterns.

\section{Results and Discussion}

The measurement results of the morphological features of each of the representative street networks and the statistical test are presented in Table 2. As it can be seen, the street pattern groups - pre-modern, modern and late modern - significantly differ according to these morphological features. The value of the curvature measure (the ratio of streets/axial lines) is close to 1 in the pre-modern street pattern, characterized by disordered orthogonal form, but it is much lower in the street patterns of the later periods, where the ratio streets/axial lines is less than 1 (i.e. more axial lines in the newer street patterns), which means relatively greater curvature. Fragmentation and fraction show much lower values in the pre-modern street pattern than in the newer patterns. This indicates that pre-modern patterns are characterized by greater continuity while the modern and late-modern street patterns are characterized by multiple dead-end streets and a high level of fragmentation. Similarly, the newer the pattern, the lower the level of spatial connectivity; patterns from the pre-modern period exhibit an average of 18.4 access lines while patterns from the modern period exhibit only 9.2 access lines. Areas exhibiting high numbers of access lines were indeed constructed in the 1950s. Although now located in the center of their cities (i.e. new towns) they are still poorly connected to the city's surroundings. Patterns from the late-modern period, being the most peripheral, are even less connected (an average of 7 access lines). As expected, differentiation exhibits lower ratios in the pre-modern period relative to the modern and late-modern period. However, the continuity of the street networks was found to vary little between the periods.

Thus, a significant difference was found between the patterns of the three examined periods, especially between the pre-modern one and the later periods. The above findings suggest that the street patterns in the older pre-modern period are relatively more orthogonal with less hierarchy and well-connected to the city core. As time passes, the patterns become more 
fragmented, less continuous and more poorly connected. A detailed examination of the differences between the newer patterns (i.e. the modern and the late-modern ones) shows a

Table 2

Morphological features of selected street networks in Israeli cities by period of establishment

\begin{tabular}{|c|c|c|c|c|c|c|}
\hline & & $\begin{array}{c}\text { Curva- } \\
\text { ture } \\
\text { SIA }\end{array}$ & $\begin{array}{c}\text { Frag- } \\
\text { menta } \\
\text { tion } \\
\text { C/S } \\
\end{array}$ & $\begin{array}{c}\text { Spatial } \\
\text { Connec- } \\
\text { tion }\end{array}$ & $\begin{array}{l}\text { Differen- } \\
\text { tiation } \\
\text { A/B }\end{array}$ & $\begin{array}{l}\text { Conti- } \\
\text { nuity }\end{array}$ \\
\hline $\begin{array}{l}\text { Periods of city } \\
\text { planning }\end{array}$ & Period & $\begin{array}{l}\text { Ratio } \\
\text { be- } \\
\text { tween } \\
\text { streets } \\
\text { and } \\
\text { Axial } \\
\text { lines }\end{array}$ & $\begin{array}{l}\text { Ratio } \\
\text { be- } \\
\text { tween } \\
\text { cul-de- } \\
\text { sac } \\
\text { and } \\
\text { streets }\end{array}$ & $\begin{array}{l}\text { No. of } \\
\text { access } \\
\text { lines be- } \\
\text { tween the } \\
\text { sampled } \\
\text { pattern and } \\
\text { the city } \\
\text { core }\end{array}$ & $\begin{array}{l}\text { Ratio of } \\
\text { no. of } \\
\text { blocks to } \\
\text { no. of } \\
\text { axial } \\
\text { lines }\end{array}$ & $\begin{array}{l}\text { T Junc- } \\
\text { tions } \\
\text { out of } \\
\text { all } \\
\text { Junc- } \\
\text { tions }\end{array}$ \\
\hline $\begin{array}{l}\text { Pre-modern - } \\
\text { Netania }\end{array}$ & $\begin{array}{l}\text { Late } 19^{\text {th }} \\
\text { century } \\
\text { until } \\
1950 \mathrm{~s} \\
\end{array}$ & 1.15 & 0.09 & 18 & 2.56 & 0.79 \\
\hline $\begin{array}{l}\text { Pre-modern } \\
\text { (sample 1) - Rishon } \\
\text { Le-Zion }\end{array}$ & $"$ & 1.02 & 0.11 & 21 & 2.10 & 0.76 \\
\hline $\begin{array}{l}\text { Pre-modern } \\
\text { (sample 2) - Rishon } \\
\text { Le-Zion }\end{array}$ & $"$ & 0.93 & 0.06 & 20 & 2.00 & 0.78 \\
\hline $\begin{array}{l}\text { Pre-modern - } \\
\text { Raanana }\end{array}$ & $"$ & 0.87 & 0.15 & 17 & 2.44 & 0.77 \\
\hline $\begin{array}{l}\text { Pre-modern - } \\
\text { Hadera }\end{array}$ & $"$ & 0.87 & 0.18 & 16 & 2.14 & 0.86 \\
\hline Average & & 0.97 & 0.12 & 18.4 & 2.25 & 0.79 \\
\hline Modern - Netania & 50's-80's & 0.69 & 0.58 & 10 & 3.21 & 0.8 \\
\hline $\begin{array}{l}\text { Modern - Rishon } \\
\text { Le-Zion }\end{array}$ & $"$ & 0.69 & 0.31 & 7 & 3.59 & 0.86 \\
\hline Modern - Eilat & $"$ & 0.55 & 0.45 & 12 & 8.08 & 0.93 \\
\hline Modern - Ashdod & $"$ & 0.52 & 0.74 & 10 & 5.15 & 0.9 \\
\hline Modern - Bat Yam & $"$ & 0.48 & 0.47 & 7 & 3.44 & 0.91 \\
\hline Average & & 0.59 & 0.51 & 9.2 & 4.7 & 0.86 \\
\hline $\begin{array}{l}\text { Late-modern } \\
\text { (sample 1) - } \\
\text { Ashdod }\end{array}$ & $\begin{array}{l}80 \text { 's till } \\
\text { today }\end{array}$ & 0.77 & 0.26 & 6 & 3.11 & 0.83 \\
\hline $\begin{array}{l}\text { Late-modern } \\
\text { (sample 2) - } \\
\text { Ashdod }\end{array}$ & $"$ & 0.30 & 0.64 & 6 & 5.13 & 0.78 \\
\hline $\begin{array}{l}\text { Late-modern } \\
\text { (sample 3) - } \\
\text { Ashdod }\end{array}$ & $"$ & 0.78 & 0.63 & 7 & 4.21 & 0.77 \\
\hline
\end{tabular}


Morphological features of selected street networks in Israeli cities by period of establishment

\begin{tabular}{|l|c|c|c|c|c|c|}
\hline & $\begin{array}{c}\text { Curva- } \\
\text { ture } \\
\text { S/A }\end{array}$ & $\begin{array}{c}\text { Frag- } \\
\text { men- } \\
\text { tation } \\
\text { C/S }\end{array}$ & $\begin{array}{c}\text { Spatial } \\
\text { Connec- } \\
\text { tion }\end{array}$ & $\begin{array}{c}\text { Differen- } \\
\text { tiation } \\
\text { A/B }\end{array}$ & $\begin{array}{c}\text { Conti- } \\
\text { nuity }\end{array}$ \\
\hline $\begin{array}{c}\text { Periods of city } \\
\text { planning } \\
\text { be- } \\
\text { tween } \\
\text { streets } \\
\text { and } \\
\text { Axial } \\
\text { lines }\end{array}$ & $\begin{array}{c}\text { Ratio } \\
\text { be- } \\
\text { tween } \\
\text { cul-de- } \\
\text { sac } \\
\text { and } \\
\text { streets }\end{array}$ & $\begin{array}{c}\text { No. of } \\
\text { access } \\
\text { lines be- } \\
\text { tween the } \\
\text { sampled } \\
\text { pattern and } \\
\text { the city } \\
\text { core }\end{array}$ & $\begin{array}{c}\text { Ratio of } \\
\text { no. of } \\
\text { blocks to } \\
\text { no. of } \\
\text { axial } \\
\text { lines }\end{array}$ & $\begin{array}{c}\text { T Junc- } \\
\text { tions } \\
\text { out of } \\
\text { all } \\
\text { Junc- } \\
\text { tions }\end{array}$ & \\
\hline $\begin{array}{l}\text { Late-modern } \\
\text { (sample 1)- Eilat }\end{array}$ & $"$ & 0.73 & 0.34 & 7 & 4.67 & 0.89 \\
\hline $\begin{array}{l}\text { Late-modern } \\
\text { (sample 3)- Eilat }\end{array}$ & $"$ & 0.33 & 0.38 & 9 & 3.37 & 0.86 \\
\hline Average & & $\mathbf{0 . 5 8}$ & $\mathbf{0 . 4 5}$ & $\mathbf{7}$ & $\mathbf{4 . 1}$ & $\mathbf{0 . 8 2}$ \\
\hline F & & $\mathbf{8 . 8 1 8}$ & $\mathbf{1 1 . 4 4 7}$ & $\mathbf{5 8 . 2 4 8}$ & $\mathbf{4 . 9 2 8}$ & $\mathbf{4 . 5 5 7}$ \\
\hline Sig. & $\mathbf{0 0 4}$ & $\mathbf{. 0 0 2}$ & $<\mathbf{0 . 0 0 0 1}$ & $\mathbf{. 0 2 7}$ & $\mathbf{0 4 4 6}$ \\
\hline
\end{tabular}

$S=$ Streets; $A=$ Axial lines; $C=$ Cul-de-sac; $B=$ blocks; $T=T$ Junctions

The bottom two lines show the results of the one-way ANOVA $(\mathrm{df}=14)$

consistent tendency over time - the intensification of the curvature and fragmentation as well as the weakening of internal and external connectivity of given street networks. Thus, the newer street patterns are more fragmented, with fewer city blocks and less connected to the city core. The one-way ANOVA comparing the street patterns of the three periods indicated a statistically significant difference between these groups $(p<0.05)$, by all the investigated morphological features.

The morphological analysis of street networks over time provides us with the following process as illustrated in Fig. 3: before the beginning of the major Zionist settlement (that is, the end of the $19^{\text {th }}$ century), an organic old pattern was indeed to be found. Grids began to appear at the start of the $20^{\text {th }}$ century created in part during the Ottoman period and in part during the British Mandate. However, the appearance of the two patterns was limited and local. In addition to these early street patterns, three additional types of patterns can be identified. Each of them represents a significant period of urban development embodying a planning approach and unique characteristics. These prototypical street patterns are as follows:

The pre-modern disordered orthogonal pattern - employed from the end of the $19^{\text {th }}$ century until the 1950s.

The modern fragmented trees pattern - employed from the beginning of the 1950s until the 1980s.

The late-modern pictorial pattern - employed from the 1980s until the present.

Each of the three main patterns is associated with a different explanation for its distribution: the disordered orthogonal pattern was in use during a few decades, from the late $19^{\text {th }}$ century till 
the 1940 s - by the first Zionist settlers. These settlers managed to establish about 30 agriculture settlements (moshavot), a considerable number of which became cities in which the core is characterized by this street pattern. The fragmented trees pattern was the major pattern adopted by government planners when building more than 30 new towns throughout the country after the establishment of the state in 1948. This pattern was also used to develop a vast number of new neighborhoods in existing cities, in many of them with an extensive implementation of the 'city garden' model, and with a city center which is separated from the residential areas. The pictorial pattern is a popular creation of the private sector, which constructed new neighborhoods wherever possible once the major period of public construction ended in the late 1980s. This explains why this pattern is found in such a large scale and in all types of cities.

The examination of the evolution of street patterns established according to distinct planning approaches - pre-modern, modern and late-modern - reveals several morphological aspects that characterize the changes that have occurred in the Israeli urban environment. The

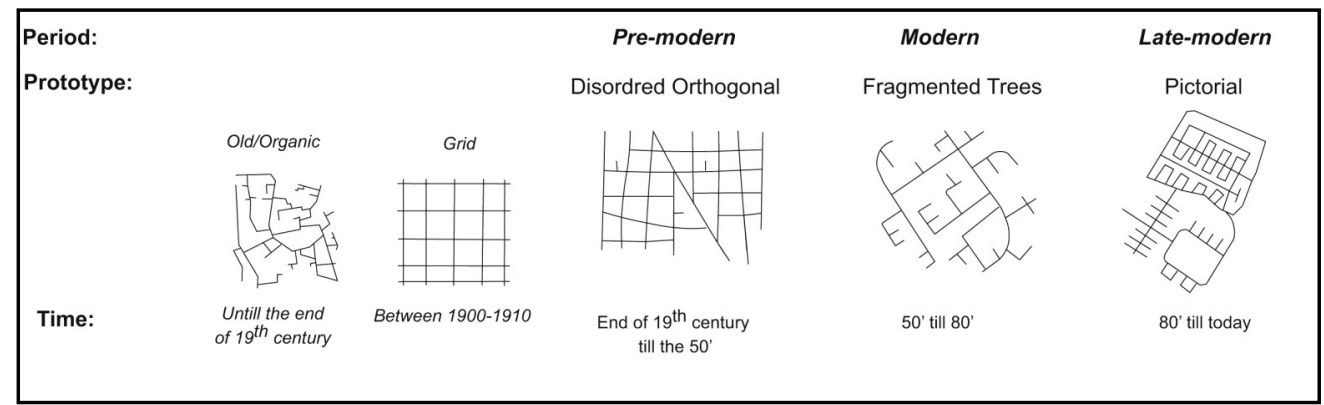

Fig. 3 - Prototypes of main street patterns found in Israeli cities, by period and planning approach

disordered orthogonal pattern, which is related to pre-modern planning, is actually a grid pattern with some distortions in the length of its lines (i.e. dead-end streets) and their direction (i.e. diagonal streets), elements that indicate the presence of initial spatial organization in the street network. The fragmented trees pattern associated with modern planning is essentially a combination of curved lines and many dead-end streets as well as many T-junctions. Thus, this pattern is characterized by the domination of spatial organization and hierarchical structure. In addition, spatial fragmentation occurs at a more-local level. The pictorial pattern that developed from the 1980s and related to late-modern planning can be viewed as the intensification of spatial fragmentation and spatial organization at higher spatial level relative to the patterns that developed during the previous three decades. This pattern reveals the much greater presence of dead-end streets as well as areas distinguishable at the global level of the pattern, which contributes to a greater spatial fragmentation. Thus, relative to the initial basic organic and grid patterns of the early pre-modern urban environments, street patterns became much more organized yet spatially fragmented over time. This finding fits those of previous research (ZafrirReuven 2006, Omer and Zafrir-Reuven 2010) that elaborated the strong relationship between city ages, period of establishment and observed street pattern.

Regarding the geographic aspects of the street patterns described above, the first pre-modern disordered orthogonal pattern is located in core areas, mainly in moshavot and semi-agriculture settlements (their location can be seen clearly in Fig. 2a, in the cities Raanana, Hadera, Netania and Rishon Le-Zion). The modern fragmented tree pattern began mainly in the peripheral New Towns (see locations in Eilat and Ashdod, in Fig. 2a) but it was slowly added in new areas of older cities (see locations in Netania, Bat-Yam and Rishon Le-Zion, Fig. 2a). By 
the 1960s, this pattern had become the dominant pattern in new marginal urban areas throughout Israel (i.e. margins of older cities). Thus, despite its massive presence, the pre-modern disordered orthogonal patterns still characterized the core of the cities, while the modern fragmented trees characterized their periphery. Only during the 1980s, the modern fragmented trees pattern became dominant. The late-modern planning approach introduced the pictorial pattern that provided some geometric order to the urban space. At first, it was significant mainly in the periphery but it currently serves as a prominent street pattern in the new neighborhoods throughout the Israeli urban space.

\section{Conclusions}

In this paper we investigated street patterns of Israeli cities by comparing three time periods of urban development, each of which is related to a different urban planning approach - the premodern, the modern and the late-modern. For this purpose, we used several morphological measures to describe the main street pattern properties: curvature, fragmentation, spatial connection, continuity and differentiation. The results indicate that clear distinctions can be found between the street patterns established according to the three examined planning approaches, each being strongly related to significant periods in the development of cities in Israel. The results show clearly constant and gradual trends in the intensification of the curvature, fragmentation and complexity level of the spatial organization of street networks as well as the weakening of the network's internal and external connectivity.

These trends in the urban street network are quite similar to what was observed in many other countries. What is unique about the Israeli case is the rapid intensive urban settlement, which combines different urban planning ideas associated with diverse socio-cultural forces. Such diversity exists at the local scale of the neighborhoods and relatively small urban areas.

The fact that the street patterns of the Israeli urban space clearly differ from one another to become more fractured, fragmented and disconnected over time has significant implications on the urban form but also on the spatial integration and functioning of cities. The study findings concerning the development of street patterns, and the impact of planning approaches on connectivity and spatial integration in this respect, may assist to deal with the present urban planning problems of sustainability and smart growth. For example, the difficulties in creating a walkable environment and integrated social and functional urban areas are associated with the modern and late-modern urban environment due to their low levels of spatial integration. However, further research on those implications can contribute to our understanding of how urban planning approaches acquired expression in the social and functional aspects of urban areas through the morphological features of street networks.

\section{References}

ALTERMAN R., HILL M. (1986), Land use planning in Israel, in: PATRICIOS N. N. (ed.), International Handbook on Land Use Planning, Greenwood Press, Westport, pp. 119-150.

ANDERSON E. (1992), Streetwise: Race, Class, and Change in an Urban Community, University of Chicago Press, Chicago.

ARAVOT I., MILITANU S. (2000), Israeli New Town Plans: Physical Transformations, Journal of Urban Design 5 (1), 41-64.

ASAMI Y., KUBAT A. S., ISTEK C. (2001), Characterization of the street networks in the traditional Turkish urban form, Environment and Planning B: Planning and Design 28 (5), 777-795.

BARAN P. K., RODRIGUEZ D. A., KHATTAK A. J. (2008), Space Syntax and Walking in a New Urbanist and Suburban Neighbourhoods, Journal of Urban Design 13 (1), 5-28. 
BATTAT - AVIRAM M. (2014), Spatial Duality: Urbanization process and social Dynamics in Israel, MA Thesis, Tel-Aviv University, Tel-Aviv.

BONINE M. E. (1979), The morphogenesis of Iranian cities, Annals of the Association of American Geographers 69 (2), 208-224.

BRUTZKUS E. (1964), Physical Planning in Israel: Problems and Achievements, Israel Ministry of the Interior, Jerusalem.

COHEN S., AMIR T. (eds.) (2008), Living forms: Architecture and Society in Israel, Xargol Books, Tel-Aviv.

CUBUKCU E., NASAR J. L. (2005), Relation of physical form to spatial knowledge in largescale virtual environments, Environment and Behavior 37 (3), 397-417. EFRAT E. (1984), Urbanization in Israel, Croom Helm, London.

EFRAT Z. (2004), The Israeli project: Building and Architecture 1948-1973, Tel Aviv Museum of Art, Tel Aviv.

FARHI J., ZAFRIR D. (2003), Our Journey into the Street - Instructions for street planning, Ministry of Construction and Housing and Ministry of Transport and Road Safety, Jerusalem.

FILION P., HAMMOND K. (2003), Neighbourhood land use and performance: the evolution of neighbourhood morphology over the 20th century, Environment and Planning B: Planning and Design 30 (2), 271-296.

GRANNIS R. (2005), T-Communities: Pedestrian Street Networks and Residential Segregation in Chicago, Los Angeles, and New York, City \& Community 4 (3), 295-321.

HAJRASOULIHA A., Yin L. (2014), The impact of street network connectivity on pedestrian volume, Urban Studies, 1-15.

HATUKA T., BAR R., JACOBSON M., LOTHAN H., BATTAT M., FAIN J. (2012), StateNeighborhood, Resling Publishing Ltd, Tel Aviv. HEBBERT M. (2005), Engineering, urbanism and the struggle for street design, Journal of Urban Design 10 (1), 39-59.

HILLIER B. (1987), The morphology of urban space: the evolution of a syntactic approach, Architecture and Behaviour 3 (3), 205-216.

HILLIER B. (1996), Space is the machine, Cambridge University Press, Cambridge. HILLIER B., IIDA S. (2005), Network and psychological effects in urban movement, in:

COHN A. G., MARK D. M. (eds.), Proceedings of the International Conference on Spatial Information Theory, Springer-Verlag, Berlin, pp. 475-490.

JACOBS A. B. (1993), Great streets, The MIT Press, Cambridge.

JACOBS J. (1961), The death and life of great American cities, Vintage, New York.

JACOBSON M. (2013), Divided Pattern of the Urban Center in New Towns in Israel, MA Thesis, Tel-Aviv University, Tel-Aviv.

JIANG B. (2007), A topological pattern of urban street networks: universality and peculiarity, Physica A 384, 647-655.

KOSTOF S. (1993), The City Shaped: Urban Patterns and Meanings Through History, Bullfinch Press, Boston.

KROPF K. (2009), Aspects of urban form, Urban Morphology 13 (2), 105-120.

LERMAN Y., OMER I. (2013), The Effects of Configurational and Functional Factors on the Spatial Distribution of Pedestrians, in: VANDENBROUCKE D., BUCHER B., CROMPVOETS J. (eds.), Geographic Information Science at the Heart of Europe, Springer, Berlin-Heidelberg, pp. 383-398.

LYNCH K. (1960), The Image of the City, The MIT Press, Cambridge.

MAROM N. (2009), City of Concept: Planning Tel-Aviv, Babel, Tel-Aviv.

MAROM N. (2014), Planning as a Principle of Vision and Division: A Bourdieusian View of Tel Aviv's Urban Development, 1920s-1950s, Environment and Planning A 46 (8), 1908-1926.

MARSHALL S. (2005), Streets and patterns, Spon Press, London.

MONTELLO D. R. (2007), The contribution of space syntax to a comprehensive theory of environmental psychology, Proceedings 6th International Space Syntax Symposium 
Istanbul, 1-12.

MOUDON A. V. (1992), The Evolution of Twentieth-Century Residential Forms: An American Case Study, in: WHITEHEAD J. W. R., LARKHAM P. J. (eds.), Urban Landscapes: International Perspectives, Routledge, London, pp. 170-206.

MOUDON A. V. (1994), Getting to know the built landscape: typomorphology, in FRANCK K. A., SCHNEECKLOTH L. H. (eds.), Ordering space: types in architecture and design, Van Nostrand Reinhold, New York, pp. 289-311. MOUDON A. V. (1998), The Changing Morphology of Suburban Neighborhoods, in: PETRUCCIOLI A. (ed.), Typological Process and Design Theory, Aga Khan Program for Islamic Architecture, Cambridge, pp. 141-157.

OLIVEIRA V. (2013), Morpho: a methodology for assessing urban form, Urban Morphology 17 (1), 21-33.

OMER I., ZAFRIR-REUVEN O. (2010), Street Patterns and Spatial Integration of Israeli Cities, The Journal of Space Syntax 1 (2), 280-295

OMER I., Goldblatt R. (2015), Spatial Patterns of Retail Activity and Street Network Structure in New and Traditional Israeli Cities, Urban Geography (online).

OMER I., ROFE Y., LERMAN Y. (2015), The impact of planning on pedestrian movement: contrasting pedestrian movement models in pre-modern and modern neighborhoods in Israel, International Journal of Geographical Information Science 29 (12), 2121-2142.

OZBIL A., PEPONIS J., STONE B. (2011), Understanding the link between street connectivity, land use and pedestrian flows, Urban Design International 16 (2), 125-141.

PALDI A., WOLSSOHN M. (1989), Changing Patterns in Neighbourhood design Confronting planning with tenants' everyday life, Ministry of Constructing and Housing, Urban Planning Department - Follow-up Field Studies, Jerusalem. PORTA S., CRUCITTI P., LATORA V. (2006), The network analysis of urban streets: a primal approach, Environment and Planning B: Planning and Design 33 (5), 705-725. PORTA S., LATORA V., WANG F., RUEDA S., STRANO E., SCELLATO S., CARDILLO A., BELLI E., CARDENAS F., CORMENZANA B., LATORA L. (2012), Street Centrality and the Location of Economic Activities in Barcelona, Urban Studies 49 (7), 1471-1488.

READ S. (1999), Space syntax and the Dutch city, Environment and Planning B: Planning and Design $26(2), 251-264$.

ROFE Y., OMER I. (2014), How urban grids generate urbanism - examples from Israel, in: CAVALLO R., KOMOSSA S., MARZOT N., BERGHAUSER PONT M., KUIJPER J. (eds.), New Urban Configurations, Delft University Press, Delft, pp. 673-678. ROTBARD S. (2015), White City, Black City: Architecture and War in Tel Aviv and Jaffa,

The MIT Press, Cambridge. SCHNELL I., BENJAMINI Y., PASH D. (2005), Research note: neighborhoods as territorial units: the case of Tel Aviv-Jaffa, Urban Geography 26 (1), 84-95.

SCOPPA M. D., PEPONIS J. (2015), Distributed attraction: the effects of street network connectivity upon the distribution of retail frontage in the City of Buenos Aires, Environment and Planning B: Planning and Design 42 (2), 354-378. SONG Y., KNAAP G.-J. (2004), Measuring Urban Form: Is Portland Winning the War on Sprawl? Journal of the American Planning Association 70 (2), 210-225. SOUTHWORTH M., BEN-JOSEPH E. (1995), Street Standards and the Shaping of Suburbia, Journal of the American Planning Association 61 (1), 65-81.

SOUTHWORTH M., BEN-JOSEPH E. (1996), Streets and the Shaping of Towns and Cities, McGrew-Hill, New-York.

SOUTHWORTH M., OWENS P. M. (1993), The Evolving Metropolis: Studies of Community, Neighborhood, and Street Form at the Urban Edge, Journal of the American Planning Association 59 (3), 271-287.

STANTON B. H. (1986), The incidence of home grounds and experiential networks. Some implications, Environment and behavior 18 (3), 299-329. 
STRANO E., VIANA M., DA FONTOURA COSTA L., CARDILLO A., PORTA S., LATORA V. (2013), Urban street networks, a comparative analysis of ten European cities, Environment and Planning B: Planning and Design 40 (6), 1071-1086.

TURNER A. (2004), Depthmap 4: a researcher's handbook, Bartlett School of Graduate Studies, UCL, London, Retrieved from: www.discovery.ucl.ac.uk.

WHEELER S. M. (2008), The evolution of built landscapes in metropolitan regions, Journal of Planning Education and Research 27 (4), 400-416.

ZAFRIR-REUVEN O. (2006), Spatial urban pattern in the Israeli city, in: HEILBRONNER O., LEVIN M. (eds.), The Israeli City: Last Hebrew City? Resling, Tel-Aviv.

Initial submission: 16.08 .2015

Revised submission: 13.10 .2015

Final acceptance: 04.12.2015

Correspondence: Department of Geography and Human Environment, Tel-Aviv University, Ramat-Aviv, Tel-Aviv, 69978, Israel

E-mail: omery@post.tau.ac.il 
